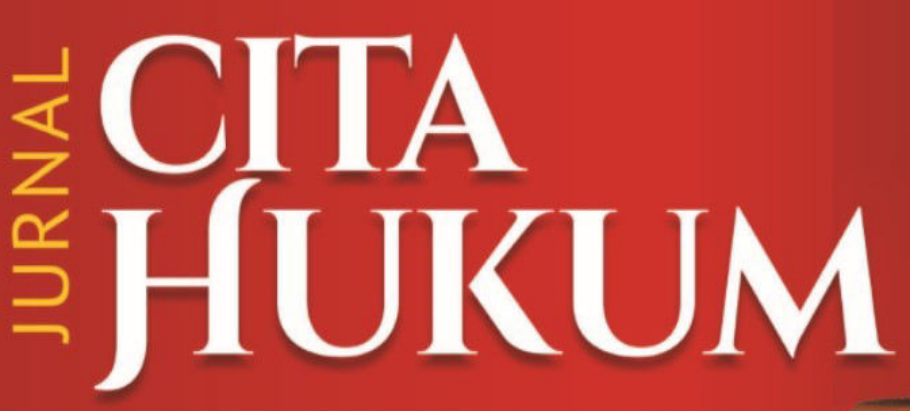

Indonesian Law Journal

- Related with Judicial Conditions in The Civil Case Evidence in The Court (Case Study of Decision No. 47 / Pdt.G / 2012 / PN Lsk and Decision No. 16/Pdt.G/2012/PN Stb)

Efa Laela Fakhriah \& Yustika Tatar Fauzi Harahap

- Model Setting of Political Party System and Electoral Systems to Prevent Political Corruption Agus Riwanto \& Achmad

- A Patient's Legal Protection as a Victim of Sexual Harassment on Medical Services in Indonesia

Siska Elvandari \& Mey Lin Chan

- Filling the Position of Constitutional Court Judge and Its Correlation with the Independence of Judges (Comparative Study of Some Countries)

M. Beni Kurniawan

- The Institutional Renewal in Settlement of Disputes of Local Election Results Heru Widodo

- The Rebellion Indication Towards Sovereign Government in Acts of Terrorism in Indonesia In Transcendental Dimension

Irfan Hielmy \& Nur Rohim Yunus

- Politik Hukum Dalam Kebijakan Hukum Pidana LGBT

Iqbal Kamalludin, Hirda Rahma, Aldila Arumita Sari \& Pujïyono

- Pengaruh Konvensi Hukum Laut Internasional Tahun 1982 Terhadap Wilayah Laut Indonesia Yoyon Mulyana Darusman

- Pengawasan Pengurus Ikatan Notaris Indonesia Kota Padang Terhadap Pelaku Pelanggaran Kode Etik

Nisaul Hasanah, Azmi Fendri \& Neneng Oktarina

Volume 6 Number 2 (2018) 


\section{Jurnal}

\section{CITA HUKUM}

\section{VOLUME 6 NUMBER 2 (2018)}

CITA HUKUM is Indonesian Law Journal published by Faculty of Sharia and Law, State Islamic University Syarif Hidayatullah Jakarta in Associate with Center for Study of Indonesian Constitution and Legislation (POSKO-LEGNAS) UIN Jakarta.

This journal specializes in Indonesian Legal Studies and try to present various results of the latest and high-quality scientific research which is issued twice in a year at June and December.

CITA HUKUM has been indexed at DOAJ, EBSCO, Microsoft Academic Search, Emerging Source Citation Index (ESCI) Clarivate Analytics, and SINTA 3 and become a CrossRef Member since year 2015.

Therefore, all articles published by CITA HUKUM will have unique DOI number.

\section{INTERNATIONAL ADVISORY BOARD}

Prof. Tim Lindsey, SCOPUS ID: 36785442900; h-index: 5, Melbourne University Australia

Prof. Muhammad Munir, Scopus ID: $54414595100 \mathrm{~h}$-index: 1, Department of Law, International Islamic University Islamabad, Pakistan Prof Mark Cammack, Scopus ID: $6507998992 \mathrm{~h}$-index: 3, Southwestern Law School Los Angeles USA

Prof. Euis Nurlaelawati, Scopus ID: 56247081700 h-index: 1, Faculty of Sharia and Law, UIN Sunan Kalijaga Yogyakarta

\section{EDITORIAL BOARD}

Prof. Gani Abdullah, h-index Google Scholar: 5, UIN Syarif Hidayatullah Jakarta

Prof. Salman Maggalatung, h-index Google Scholar: 3, UIN Syarif Hidayatullah Jakarta

Dr. Asep Saepudin Jahar, Scopus ID: 57156653300, h-Index Google Scholar: 1, UIN Syarif Hidayatullah Jakarta

Dr. Ahmad Tholabi Kharlie, Thomson Reuters Id: R-5028-2017, h-Index Google Scholar: 3, UIN Syarif Hidayatullah Jakarta

\section{EDITOR IN CHIEF}

Nur Rohim Yunus, Thomson Reuters Researcher ID: F-3477-2017, ORCID ID: 0000-0003-27821266, SSRN ID: 2645355, h-index Google Scholar: 4, Department of Constitutional Law, UIN Syarif Hidayatullah Jakarta, Indonesia

\section{MANAGING EDITOR}

Muhammad Ishar Helmi, Thomson Reuters Researcher ID: F-3345-2017, ORCID ID: 0000-0001-7060-8191, h-index Google Scholar: 2, Department of Criminal Law UIN Syarif Hidayatullah Jakarta, Indonesia

\section{EDITORS}

Indra Rahmatullah, ORCID ID: 0000-0002-6160-4225, h-index Google Scholar: 2, Department of Economic Law, Faculty of Sharia and Law, UIN Syarif Hidayatullah Jakarta, Indonesia.

Mara Sutan Rambe, ORCID ID: 0000-0001-5404-6635, h-index Google Scholar: 1, Department Criminal Law, Faculty of Law, UIN Syarif Hidayatullah Jakarta, Indonesia.

\section{ENGLISH LANGUAGE EDITOR}

Fitria, ORCID ID: 0000-0001-9733-1233, Department of International Law, York Law School, University of York, UK, United Kingdom.

\section{ASSISTANT TO THE EDITORS}

Erwin Hikmatiar, Thomson Reuters Researcher ID: F-3235-2017, ORCID ID: 0000-0003-4103-818X, UIN Syarif Hidayatullah Jakarta

\section{Redaktur Office}

Faculty of Sharia and Law UIN Syarif Hidayatullah Jakarta

Street Ir. H. Juanda 95 Ciputat Jakarta 15412

Phone. (62-21) 74711537, Faks. (62-21) 7491821

Website: www.fsh-uinjkt.net, E-mail: jurnal.citahukum@uinjkt.ac.id

Link: http://journal.uinjkt.ac.id/index.php/citahukum 


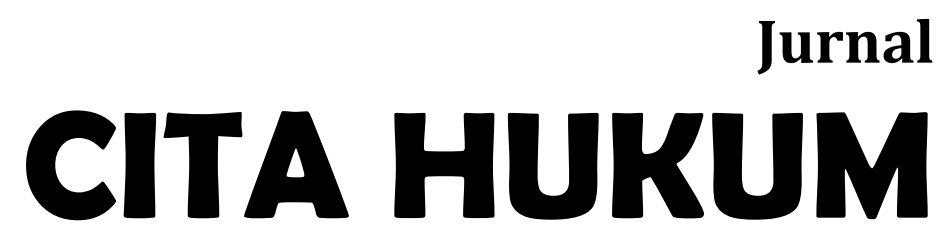

INDONESIAN LAW JOURNAL

Welcoming contributions from scientists, scholars, professionals, and researchers in the legal disciplines to be published and disseminated after going through script selection mechanisms, reviewing sustainable partners, and rigorous editing processes. 


\section{TABLE OF CONTENTS}

Related with Judicial Conditions in The Civil Case Evidence in The Court (Case Study of Decision No. 47 / Pdt.G / 2012 / PN Lsk and Decision No. 16/Pdt.G/2012/PN Stb)

Efa Laela Fakhriah, Yustika Tatar Fauzi Harahap 201-216

Model Setting of Political Party System and Electoral Systems to Prevent Political Corruption

Agus Riwanto, Achmad $217-234$

A Patient's Legal Protection as a Victim of Sexual Harassment on Medical Services in Indonesia

Siska Elvandari, Mey Lin Chan.

$235-252$

Filling the Position of Constitutional Court Judge and Its Correlation with the Independence of Judges (Comparative Study of Some Countries)

M. Beni Kurniawan. 253-276

The Institutional Renewal in Settlement of Disputes of Local Election Results Heru Widodo 277-292

The Rebellion Indication Towards Sovereign Government in Acts of Terrorism in Indonesia In Transcendental Dimension

Irfan Hielmy, Nur Rohim Yunus 293-316

Politik Hukum Dalam Kebijakan Hukum Pidana LGBT (Legal Politics in the LGBT Criminal Law Policy)

Iqbal Kamalludin, Hirda Rahma, Aldila Arumita Sari, Pujiyono $317-342$

Pengaruh Konvensi Hukum Laut Internasional Tahun 1982 Terhadap Wilayah Laut Indonesia (The Influence of the 1982 International Convention on the Law of the Sea against the Indonesian Ocean Territory)

Yoyon Mulyana Darusman $343-360$

Pengawasan Pengurus Ikatan Notaris Indonesia Kota Padang Terhadap Pelaku Pelanggaran Kode Etik (Supervision of the Management of the Indonesian Notary Association in Padang City Against Perpetrators of the Code of Ethics)

Nisaul Hasanah, Azmi Fendri, Neneng Oktarina 361-386 



\title{
Urgency Application of Proof Decisoir Eed Related With Judicial Conditions In The Civil Case Evidence In The Court* \\ (Case Study of Decision No. 47 / Pdt.G / 2012 / PN Lsk and Decision No. 16/Pdt.G/2012/PN Stb)
}

\author{
Efa Laela Fakhriah, ${ }^{1}$ Yustika Tatar Fauzi Harahap ${ }^{2}$ \\ Faculty of Law, University of Padjadjaran, Bandung, Indonesia
}

DOI: $10.15408 /$ jch.v6i2.8686

\begin{abstract}
:
Implementation of the law that related civil law to the procedure of settlement of the legal dispute in court is regulated by formal law that named law of civil procedure. The aim of this study to determine how the application of proof decisoir eed in Civil Case Evidence in Court? and how the factors that affect the consideration of the judge in deciding decisoir eed as evidence? There are some references for this research, court decisions, both decisoir eed application by either party in order to convince the judge and decisoir eed as the only evidence of the evidentiary process. The results showed that contradictory opinions; In practice there are judicial decisions that apply oath breaker even if the parties have filed written evidence and witnesses; and decisoir eed can be applied if one of the parties did not submit evidence. The next discussion is the existence of subjective factors and objective factors for the judge to consider the granting of the decisoir eed by the parties. The conclusion of this research is the application of the decisoir eed of the civil event is irrelevant because of the low sense of legal certainty.
\end{abstract}

Keywords: Proof, Decisoir Eed, Judge

*Received: July 17, 2018, revised: August 20, 2018, Accepted: November 11, 2018.

1 Efa Laela Fakhriah is a Professor of Law at Department of Law, University of Padjadjaran, Bandung West Java. E-mail: efalaela@yahoo.com. Orcid ID: https://orcid.org/0000$\underline{0002-2425-2208 .}$.

2 Yustika Tatar Fauzi Harahap is a lecturer at Department of Law, University of Padjadjaran, Bandung West Java. E-mail: yustika@gmail.com. 


\title{
Urgensi Penerapan Alat Bukti Sumpah Pemutus (Decisoir Eed) Berkaitan Dengan Keyakinan Hakim Dalam Pembuktian Perdata Di Pengadilan (Studi Kasus Putusan No. 47/Pdt.G/2012/PN Lsk dan Putusan No. 16/Pdt.G/2012/PN Stb)
}

\begin{abstract}
Abstrak:
Implementasi hukum yang berhubungan di bidang keperdataan terhadap tata cara penyelesaian sengketa hukum di pengadilan diatur oleh hukum formil yang disebut dengan hukum acara perdata. Penelitian ini bermaksud untuk mengetahui bagaimana penerapan alat bukti sumpah pemutus dalam pembuktian perkara perdata di Pengadilan dan bagaimana faktor-faktor yang mempengaruhi terhadap keyakinan Hakim dalam memutuskan sumpah pemutus. Materi pembahasan penelitian ini adalah permohonan sumpah pemutus oleh salah satu pihak dengan tujuan untuk meyakinkan Hakim dalam menilai kebenaran alat bukti dan permohonan sumpah pemutus sebagai alat bukti satu-satunya dalam proses pembuktian. Hasil analisis menunjukkan 2 (dua) pendapat saling kontradiktif yaitu dalam Putusan No. 47/Pdt.G/2012/PN Lsk Majelis Hakim yang mengabulkan permohonan sumpah pemutus oleh Penggugat meskipun Penggugat telah memiliki alat bukti lain dan dalam Putusan No. 16/Pdt.G/2012/PN Stb Majelis Hakim tidak mengabulkan permohonan sumpah pemutus dalam perkara tersebut karena Pihak Lawan memiliki bukti surat dan saksi. Pembahasan berikutnya sehubungan dengan faktor subyektif dan faktor obyektif dari Hakim dalam mempertimbangkan permohonan sumpah pemutus oleh para pihak. Kesimpulan yang didapat adalah penerapan alat bukti sumpah pemutus dalam acara perdata sudah tidak relevan karena jauh dari rasa kepastian hukum dan paradigma hukum yang berkembang dalam penanganan perkara perdata di samping mencari kebenaran formal mulai mengarah kepada terwujudnya kebenaran materiil terbatas. Hakim harus melakukan pencarian kebenaran terhadap fakta yang dipersengketakan demi terwujudnya keadilan dan kepastian hukum.
\end{abstract}

Kata kunci: Alat Bukti, Sumpah Pemutus, Hakim

\section{Recommended Citation:}

Fakhriah, Efa, and Fauzi Harahap, Yustika. "Urgency Application Of Proof Decisoir Eed Related With Judicial Conditions In The Civil Case Evidence In The Court (Case Study of Decision No. 47/ Pdt.G / 2012 / PN Lsk and Decision No. 16/Pdt.G/2012/PN Stb)" JURNAL CITA HUKUM [Online], Volume 6 Number 2 (2018) 


\section{Introduction}

A civil material law is manifested in the form of law and unwritten law which is a guideline for citizens to do or not to do in society. ${ }^{3}$ Civil law material aims to protect the human interest, while civil procedure law is intended to guarantee the obedience of civil law civil material. The objective of civil procedure law is the achievement of legal order, because if the way of acting to defend the disturbed rights and interests is done not through the judiciary then there will be an act of eigenrichting. ${ }^{4}$

The provisions of the Civil Procedure Law which became the formal civil law in Indonesia is the design of H.L. Wichers to J.J. Rochussen was enacted on 5 April 1848 through Stb. Number 16 of 1848 and reinforced by the decision of King Number 93 the Year 1849. As such, the new Indonesian Regulation for Java and Madura or het Herzein Indonesisch Reglement is applied based on Stb. No. 44 the Year 1941 (hereinafter referred to as HIR) and Reglement of Seberang Regional or Rechtsreglement voor de Buitengewesten based on Stb: No. 227 of 1927 (hereinafter referred to as RBg) as well as for the European class is used Reglement op de Burgerlijke Rechtsvordering (hereinafter referred to as $\mathrm{Rv}) .^{5}$

The provision of civil law is an application of the consequences of Article II of the Transitional Provisions of the 1945 Constitution which considers Burgerlijk wetboek as the Civil Procedure Code, but with the approval of the Supreme Court on the idea of Sahardjo and Wirjono Prodjokoro thinking that the Burgerlijk wetboek voor Indonesia is not a book but only as a law book (rechtsboek), therefore the Supreme Court issued Circular Letter of Supreme Court Number 3 Year 1963 (hereinafter referred to as SEMA No. 3 Year 1963). At the end of the birth of SEMA No. 3 Year 1963 became controversial because it is unacceptable by the jurists because it creates legal uncertainty. ${ }^{6}$

In contrast to the Dutch that has done patchwork code of its civil law, but still with a framework that remains intact because it has been done amanded

\footnotetext{
3 Sudikno Mertokusumo, Hukum Acara Perdata Indonesia Edisi Revisi, (Yogyakarta: PT. Liberty, 2013), p.1.

${ }^{4}$ Efa Laela Fakhriah, Perbandingan HIR dan RBg Sebagai Hukum Acara Perdata Positif Di Indonesia, (Bandung: PT. Keni Media, 2015), p.7

${ }_{5}$ Abdulkadir Muhammad, Hukum Perdata Indonesia, (Bandung: PT. Citra Aditya Bakti, Bandung, 2012), p.3.

${ }^{6}$ Rachmadi Usman, Perkembangan Hukum Perdata Dalam Dimensi Sejarah dan Politik Hukum di Indonesia, (Jakarta: PT. Sinar Multi Press, 2003), p.240
} 
since 1838.7 Wetboek van Burgerlijke Rechtsvordering (hereinafter referred to as $\mathrm{BRV}$ ) or Code of Civil Procedure (hereinafter referred to as CCP). Important and unregulated principles in civil procedure law in Indonesia as referred to in Article 152 paragraph (1), (2) of the CCP. 8

The principle in Article 152 paragraph (1) of the CCP is to provide that evidence can be given in all forms unless provided on the contrary. Therefore, in most cases, there is no limit to the evidence given, meaning that the Dutch legal system does not recognize the so-called Numerus clausus or evidence restrictions. ${ }^{9}$ The principle in Article 152 paragraph (2) The CCP evaluates the evidence submitted to the court's discretion, unless the law provides otherwise, where the Judge must prove the case with certain evidence if there is no compulsion proof.

The new Dutch civil law does not adhere to evidentiary standards, then the Judge who decides cases other than on the basis of his belief but within the limits set by the statements of facts. The judge freely evaluates the evidence and needs to be assured that the facts have been proven, except for certain rules such as the compulsory proof set forth in Article 152 (2) of the CCP. Some of the evidence that is still specifically regulated is Article 156 CCP on document evidence (schriftelijk bewijs), Article 163 of the CCP of the witness evidence (getuigen bewijs) and includes witnesses from the parties, Article 194 CCP on the Experts (deskundigen bericht) and Article 201 CCP local examination (plaats opneming), and (gerechtelijke erkentenis), while evidence not covered in the Code of Civil Procedure is a presupposition and an oath.

In Indonesia the proof of oath is still regulated in Article 155 HIR Article 158 HIR / Article 182 RBg - Article 185 RBg, Article 177 HIR / Article 314 RBg, and Article 1929 Civil Code up to Article 1945 Civil Code. According to Sudikno Mertokusumo the meaning of oath in general is a solemn statement given or spoken at the time of promises or information by remembering the

\footnotetext{
${ }^{7}$ Efa Laela Fakhriah, Bukti Elektronik dalam Sistem Pembuktian Perdata, (Bandung: Alumni, 2011), p.131.

${ }^{8}$ Artikel 152 (1) Code of Civil Procedure: Bewijs kan worden geleverd door alle middelen, tenzij de wet anders bepaalt.

Artikel 152 ayat (2) Code of Civil Procedure: De waardering van het bewijs is aan het oordeel van de rechter overgelaten, tenzij de wet anders bepaalt.

9 The principle of numerus clausus is the concept of property law that limits the number of rights that the court will recognize as a "property" character. Associated with the unknown principle of numerus clausus in the legal system of Dutch proof, this means that basically, the evidence in the Dutch legal system is not limited.
} 
Almighty nature of God, and believing that those who give false promises or promises will be punished by Him." 10

HIR itself mentions there are 3 (three) types of oaths as evidence, namely decisoir eed, suppletoir, and aestimator, schattingseed. The decisoir shall be an oath which by one party (may the plaintiff or Defendant) be instructed to the other party to rely on the decision of the case on the pronunciation or the appointment of the oath. ${ }^{11}$ The oath charged at the request of one of the parties to its opponent is provided for in Article $156 \mathrm{HIR} / 183 \mathrm{RBg}^{12}$ and Article 1930 Civil Code. ${ }^{13}$ This decisoir may be charged and ordered although there is no proof at all, so that the imposition of this decisoir may be made at any time during the investigation in the court. ${ }^{14}$

The initiative to burden the decisoir comes from the party who orders or decides the deferent and it is the deferent who makes the oath formation. The decisoir may be borne by anyone who can be a party in a case individually or by a person duly authorized by an authentic deed (Article 157 HIR/184 RBg, Article 1945 Civil Code).

R. Subekti opines that the decisoir eed has the nature and power of litis decisoir ${ }^{15}$ for example a dispute concerning not yet or already paid the price of the goods, then the sworn only on the payment of the price instead of receiving the goods. The disclosure of the decisoir eed then automatically terminates the proceedings of the case and the law attaches to the decisoir eed the value of the perfect, binding, and decisive powers of evidence instructing the oath to the opponent to be defeated or without the possibility of applying for other evidence.

${ }^{10}$ Sudikno Mertokusumo, Hukum Acara Perdata Indonesia Edisi Revisi, h. 197.

${ }^{11}$ M. Yahya Harahap, Hukum Acara Perdata: Gugatan, Persidangan, Penyitaan, Pembuktian, dan Putusan Pengadilan, (Jakarta: Sinar Grafika, 2012), p.750.

${ }^{12}$ Article 156 HIR: "Even if there is no information to enforce a lawsuit or it over the lawsuit, one party requests that the other party be sworn before the Judge, to make a decision depending on it, provided the oath is of one act committed by that person, rather than the oath it will depend. If the deed is, an act perpetrated by both parties, then he, who does not want to swear it, can refuse the oath to his opponent. Whosoever shall be sworn, but he will not swear or swear an oath to his opponent, nor anyone who swears, but the oath is rejected to him and he is reluctant to swear it will be defeated."

${ }^{13}$ Article 1930 Paragraph (2) of the Civil Code: "Oath of the breaker may be commanded in any dispute except in the case that neither party has entered into a peace or in the case of their admission shall not be considered. The breaker's oath may be ordered at every level of the case, even in the absence of any verification attempt to prove the claim or the necessary oath-taking.

${ }^{14}$ Sudikno Mertokusumo, Hukum Acara Perdata Indonesia Edisi Revisi, p.200.

${ }^{15}$ R. Subekti, Hukum Pembuktian, (Jakarta: PT. Pradnya Paramita, 2010), p.61. 
On the contrary, the defeated party alleges that the oath appointed by the counterpart is false, the other party may file a complaint with the competent authorities and request that the party taking the oath is required in the criminal case for the false indictment referred to in Article 242 of the Criminal Code.

The judge's decision based on this oath is in fact somewhat different than the ordinary decision because this decision is essentially a dispute resolution under the hands of the litigants themselves. The judge's decision is only to give an end to the settlement. ${ }^{16}$

Suppletoir is the oath ordered by the Judge because of its position to either party to complete the proof of the dispute as for the basis of the decision. The suppletoir is governed in Article 155 of HR/182 RBG. In Article 1940 the Civil Code explains the supplementary oath can only be ordered by the Judge to one of the litigants if there is already a beginning of proof, but still not sufficient and no other evidence. The power of proof of suppletoir or enhancement oath is perfect and still enables the proof of the opponent.

Schattingseed is the oath ordered by the Judge because of its position to the plaintiff to determine the amount of compensation money. ${ }^{17}$ The schattingseed is governed in Article $155 \mathrm{HIR} / 182 \mathrm{RBg}$ and Article 1940 of the Civil Code, whereas in the trial the plaintiff is unable to prove the actual amount of compensation or the value of the price of the goods, as well as the Defendant is unable to prove his rebuttal of the compensation or the price of the goods the actual estimation of the compensation or the price of the item may be determined by the imposition of the oath of the assessor, the evidentiary power of the schattingseed that is perfect and still enables the proof of the opponent.

The schattingseed can only be charged by the Judge to the plaintiff if he has proven his right to remedy the damages. The oath may be used by the Judge if he believes that existing evidence can not determine the magnitude of the loss and the oath may also be made at the mosque. ${ }^{18}$ The evidentiary power of the schattingseed is perfect and still allows the proof of the opponent.

The existence of some incidents which need not be proved or deemed impossible to be known by the judge, which means that the truth of the event doesn't need to be proved one of them in the case of a decisoir eed, the oath is

\footnotetext{
${ }^{16}$ Efa Laela Fakhriah, Perbandingan HIR dan RBg Sebagai Hukum Acara Perdata Positif Di Indonesia, p.7.

${ }_{17}$ Efa Laela Fakhriah, Perbandingan HIR dan RBg Sebagai Hukum Acara Perdata Positif Di Indonesia, p.198.

${ }^{18}$ Sudikno Mertokusumo, Hukum Acara Perdata Indonesia Edisi Revisi, p.200.
} 
decisive, the event of dispute, are considered to be proven and require no further proof. ${ }^{19}$

In some provisions, the civil law legislation has attached the value of the perfect, binding and decisive power of proof to the presence of authentic deed instruments, the recognition before the Judge and the decisoir eed. Theoretically, the law of evidence on civil cases applied the basis of the theory of the discovery of truth based on the evidence of a limitation nature and the duty of the Judge is to accept the evidence presented by the parties without any necessity to use beliefs that question the history or authenticity of evidence. In practice in court in certain cases, Judges are required to judge the truth between evidences of one another so as to require at least 2 (two) evidence and the judge's judgment is required on the evidence presented not the incident. Hence there is a shift in theory which initially seeks only the formal truth towards the Judge in addition to seeking formal truth, as well as must seeking the material truth that is limited.

In practice as in Decision No. 47/Pdt.G/2012/PN LS, 20 the request of the Plaintiff's decisoir eed with the aim of appraising the truth of the evidence so that the Judge obtains confidence and Decision No. 16/Pdt.G/2012/PN.STB ${ }^{21}$ request for decisoir by the Plaintiff on the reason that the Plaintiff can not show the main evidence or authentic deed in the court.

Based on the explanation of 2 (two) cases above, the parties are also required to understand and apply correctly the law of evidence in the civil case in court. Justice seekers should know in general the settlement of a case must use or show evidence at the time of court proceedings.

Departing from what was mentioned in the background section above, then the main issue is how to apply the evidence of oath breakers in the provision of civil cases in the Court? and What are the factors that influence the judge's belief in granting the request of the decisoir eed?

\section{Judge Considerations}

The Judge's understanding as a representation of the judiciary must understand the case and the evidence presented by the parties in the hearing. In

\footnotetext{
${ }^{19}$ Sudikno Mertokusumo, Hukum Acara Perdata Indonesia Edisi Revisi, p. 140.

${ }^{20}$ Decision No. 47/Pdt.G/2012/PN.LSK on April 05 2013, Dalam Perkara Antara Ir. H. Syukri Daud Lawan Nasir Bin Nafi, Nurlaila A. Chaled.

21 Decision No. 16/Pdt.G/2012/PN.STB on January 08 2013, Dalam Perkara antara Indrawati alias Wong Siok Ien lawan Sabarbudi, Lie Lien Yong.
} 
general a case can only be resolved by using or showing evidence if the Judge applies other than as stipulated in the legislation must be accompanied by a logical and rational legal consideration.

The law determines the right granted to the parties to file the swearingin oath, so the initiative to swear only comes from the litigant. The Judge's duty is to grant or not to grant the request, then the Judge must have an understanding of the decisoir eed. The judge also considers if the opposing party refuses or does not want to swear and return the oath to the party who requested it.

This discussion shows that there are different views of judges in the application of evidence of decisoir eed in the civil evidence in court and there are several factors that influence the judge's confidence in obeying the request of it . It is necessary to emphasize the notion of seeking material truth here is not the absolute material truth in a criminal case, but the concept of material truth is limited or in other words, Judge in examining civil cases not only limited to formal truth. Unlike the handling of civil cases in a country with a socialist system in which the Judge has the initiative if there is any doubt about the truth that arises and the collection of evidence beyond the facts posed by the parties is allowed.

A brief chronology of the case no. 47/Pdt.G/2012/PN LSK namely the Defendants in the argument of the lawsuit stating that the Defendants have debts to the Plaintiffs in the form of 1. Borrowing money from Rp. 400,000,000 (four hundred million rupiah) with the guarantee of a Power of Attorney to sell on a plot of land owned by the Defendants and has been made Notarial Deed. 09 and No. 10 dated June 16, 2010, 2. The Defendants have the rest of the debt to the Plaintiff for the purchase of sugar of Rp. 959.035.000.- (nine hundred fifty nine million thirty five thousand rupiah) or comparable to 1980 sacks of sugar, 3. The Defendants also have not paid their debts on the purchase of Plaintiff's rice as much as $149,773 \mathrm{Kg}$ for $\mathrm{Rp} .711,421,750.00$ (seven hundred eleven million four hundred twenty-one thousand seven hundred and fifty rupiah). So the total amount of the Defendants' debts to the Plaintiffs is Rp. 959.035.000,00 Rp. $711.421 .750,00+$ Rp. $400.000 .000,00$ with the total amount of Rp. 2,070,456,750.00.

With respect to the lawsuit argument above, the plaintiff shall request to the Panel of Judges to perform the decisoir eed in the Lhoksukon District Court of Musholla against the truth of the letter of agreement dated February 17, 2012, and the invoice bill in Exhibit P-II.B, P-II.C, P-II. D, and P-II.E. The Panel of Judges who adjudicated the Aquo case granted the petition with the following oath: 
1. A letter of agreement dated February 17, 2012 stating that there has been a sale and purchase transaction between the Plaintiffs as the seller and the Defendants as the buyer of rice as much as $149.773 \mathrm{Kg}$ with the total price of Rp. 711.421.750,00

2. The correct invoice in the evidence of P-II.B, P-II.C, P-II.D, and P-II.E show the Defendants have never paid their debts to the Plaintiffs.

The Plaintiff believes in the decisoir eed against the truth of the evidence bringing the legal consequence of the truth of the event from the evidence requested by the oath to be certain that it is appropriate for the law to be declared valid and legally enforceable. As in Article 1338 Paragraph (1) of the Civil Code "All agreements made lawfully in accordance with the law shall apply as a law to those who make it" so that the Letter of Agreement dated February 17, 2012 which the decisoir eed shall be duly according to law shall be declared valid and legally enforceable.

The Plaintiff did not argue if the Defendants had paid the rice purchase debt of Rp. 48.750.000,00, The Defendants had payment of sugar purchase payable of Rp. 59.015.000,- (ninety million fifteen thousand rupiah, whereas the Plaintiff disagreed in the case of non-repayment due to the debt can not be repaid due to high interest on the debt.

Based on the legal considerations above, the panel of judges who adjudicated the case no. 47/Pdt.G/2012/PN LSK provides the following verdict: 1). To grant the Plaintiff's claim in part; 2). Define the Defendants' debts against the Plaintiff as much as the sugar debt of Rp. 840.785.000,00 + rice debt of Rp. $662,671,750.00+$ cash debt of Rp.400.000,00 with total amount of Rp.1,903,456,750.00, 3). Declare the Defendants to have broken the pledge (Default) against the Plaintiff, 4). Punish the Defendants to pay the debts to the Plaintiff on cash, immediately and unconditionally or any burden, 5). Refusing the lawsuit other than and beyond, 6). Punishing the Defendants to pay the cost of the case up to now estimated at Rp.831.000,00, which further Amar's decision on the First Tribunal has been upheld in Decision No. 61/PDT/2013/ PT. BNA and Decision No. 1085 K/Pdt/2014.

This has been a misperception of the use of the decisoir eed above, because the loading of it may be made if the lack of evidence other than the decisoir eed. In the aforementioned case it is clear that the purpose of the decisoir eed by the parties is only to convince the Panel of Judges, whereas the Panel of Judges also has the authority to use other suppletoir and schattingseed in order to 
find confidence or doubt on evidence in the form of agreement and invoice filed by the Plaintiffs.

It should be proved that the debt agreement of the receivables is contrary to the law, public order and morality or not, because if contradictory may cause the contract to be void by law. As previously stated, the Defendants recognize the payment of the debt that has been settled and the unpaid debt payment due to the high interest-rate by the Plaintiff.

The provisions concerning interest have been regulated in the Civil Code, ${ }^{22}$ so in the context of the interest payment of debt the Panel of Judges must have knowledge and beliefs about the agreement that has been made so as to provide legal certainty for the parties. The Panel of Judges shall observe the determination of interest in the condition of the financial ability of the debt, the inability to repay fully and the ability to repay partly in stages or in installments.

Regarding the signatures of the Defendants and Plaintiffs in order to prove the achievements promised by both parties. The signature has not yet determined that the agreement is made by an equally strong party in the absence of a one-sidedness to incriminate the weaker party, resulting in a misappropriation of the occasion or misuse of circumstances or misbruik van omstandigheden.

In contrast to the previous case which emphasized the Judge's belief process, it was explored by means of evidence assessment, Case No. 16/Pdt.G/ 2012/PN STB is directed towards factors that influence the judge's belief in granting the application or not from the decisoir eed. Beginning of the problem around 1971 Plaintiff has a shop as stated in the Property Right Certificate. 17 Asembagus Village, on behalf of Indrawati aka Wong Siok Ien (hereinafter referred to as SHM No. 17).

In 1975 Defendant I borrowed SHM No. 17 of the Plaintiffs to be used as collateral for credit at BNI 46, so that the Plaintiffs signed its credit verband

${ }^{22}$ Article 1236 Civil Code "the debtor is obliged to compensate the cost, loss, and interest to the debtor, if he has brought himself in a state unable to surrender his object, or has not cared properly for saving him".

Article 1767 Civil Code "There is interest according to the stipulation of the law, some of which are stipulated in the agreement. Interest by law is interest determined by law. The interest set in the agreement may exceed the interest of the law in all matters which is not prohibited by law. The amount of interest stipulated in the agreement must be stated in writing. "

Article 1768 Civil Code "If the lender agrees to the interest without specifying the amount, then the Borrower shall pay interest according to law." 
deed on November 10, 1976 and the debt was paid by Defendant I in accordance with the contents of the letter, but SHM no. 17 are not returned to the Plaintiffs otherwise SHM No. 17 has switched from the Plaintiff's name to the name of the Defendant I based on Grant Deed No. 98/ASBGS/1978 dated June 15, 1978 was made before Adnan as PPAT of Asembagus area. (hereinafter referred to as Deed Grant No. 98/ASBGS/1978).

Plaintiffs in his lawsuit argue never grant with SHM no. 17 to Defendant I because the Plaintiff never signed the Grant Deed. 98/ASBGS/1978 and facing Adnan as PPAT of Asembagus area. On the above occurrence, the Plaintiff sought a copy or file of Aka Grants no. 98/ASBGS/1978 by visiting the District Office of Asembagus and the Land Office, Situbondo Regency to check the signature on Grant Deed. 98/ASBGS/1978.

Based on the statement of the Asembagus subdistrict head Muhammad Ma'ruf, through the letter No. 590/144/431.515.2/2012 dated June 5, 2012 informed that the deed and its warkah in the District Office of Asembagus not found/did not exist, then the Plaintiff came to the Office of BPN of Situbondo Regency, according to the Head of the BPN Office through his letter said that the Deed of Grant has damaged by the flood.

The new plaintiffs know if SHM is no. 17 has transferred from Defendant I to Defendant II based on the Deed of Sale and Purchase No. 12/Asembagus/2002 dated July 23, 2002 made before Irina as Notary/PPAT (hereinafter referred to as AJB No. 12/Asembagus/2002) and issuance of a substitute certificate in the name of Defendant II even if the Plaintiff's knowledge is currently occupied by Defendant I.

A plaintiff in the lawsuit filed a request to be settled by using the proof decisoir eed as provided for in Article 156 HIR and Article 1930 Civil Code for the following reasons:

1. Plaintiff can not show the main evidence of warkah letter.

2. Decisoir eed as the starting point of termination of the case (litis decisoir) then the case can be resolved quickly so that in accordance with the principle of a judgment, and the verdict is a verdict that is really just for the sake of Justice under the Almighty God.

The Plaintiff commands the Defendant I to perform the decisoir eed with the oath made by the Plaintiff or may return it to the Plaintiff with the oath editorial made by Defendant I as a follower of the Budah religion (Tri Dharma) held at Hoo Tong Bio Temple, Ikan Gurami street, number 54 Banyuwangi. 
The consideration of the Panel of Judges concerning the status of the transfer of land rights to the object of dispute based on grant namely Article 1682 Civil Code of Hibah can only be done through notary deed which in the case of immovable goods is done through PPAT deed and the certificate of property rights has the most powerful and the most perfect the highest of the base of ownership rights over other land in accordance with the provision of Article 20 of Law no. 5 of 1961 on the Basic Agrarian Law.

Related to the sale and purchase of land and buildings have been recorded through AJB no. 12/ASBGS/VII/2002 thus the sale and purchase of land between Defendant I and Defendant II conducted with a deed made by PPAT have been in accordance with the provisions of Article 37 of Government Regulation no. 24 of 1997 on Land Registration and Defendant II obtained land by way of legal sale and purchase under the provisions of legislation so that it is a good buyer and based on the principle of law then as a good-faith buyer must also get legal protection.

Based on the legal considerations above, the panel of judges who adjudicated the case number Decision 16/Pdt.G/2012/PN STB provides the following verdict: 1 . Refusing the Plaintiff's claim for all 2. Punishing the Plaintiff to pay the case fee of Rp. 1,017,000,- (one million seventeen thousand Rupiah).

The decisoir eed is the ultimate proof for the party to prove the deeds done or the acts committed by two parties. In the case of such act is done both sides while the party who is ordered to swear not be able to return the oath to his opponent then the Panel of Judges must consider in its verdict. On the contrary, the action is carried out by the party under oath, therefore the oath can not be returned to the opponent who does not participate in the deed.

Judge's consideration of the decisoir eed in case No. 16/Pdt.G/2012/PN STB which is based on Article 156 HIR and Article 1930 Paragraph (2) of the Civil Code, the Panel of Judges in determining and deciding the burden of the decisoir eed against the parties shall prioritize the fulfillment of formal conditions for violation of the law of condition, a formal requirement of a civil event which may result in a decision null and void and the Panel of Judges is of the opinion that the imposition of the decisoir eed required by the Plaintiff to the Defendant I do not meet the formal requirements in accordance with the jurisprudence of Supreme Court Decision No. 575 K/Sip/1973 "the solicitation of the decisoir eed can only be granted if in any case there is absolutely no evidence." 
Although the Defendants have submitted proof of letter in the form of Exhibit T-1, Exhibit T-2, Exhibit T-3 and Exhibit T-4 and 2 (two) witnesses 1. Heri Prihantoro, S.Sos, and 2. Sukak Farida, the Panel of Judges granted the request of the oath because Defendant I also did not object to the loading of the decisoir eed required by the Plaintiff. Judge Consideration above has disregarded the rights of the Plaintiffs who wish to use the proof decisoir eed.

There are 2 (two) opinions, first the Judge understands the nature of the solicitation of the decisoir eed can only be granted if in a case there is absolutely no evidence of the parties or both the solicitation of the decisoir eed can only be granted if in a case there is absolutely no evidence from the arguing party (Plaintiff) or acts committed by the person himself under oath.

To find laws related to "decisoir eed can only be granted if in no case there is absolutely no evidence" using the method of interpretation and construction methods in terms of interpreting those words. In the case of the existing regulations, it is not clear to apply to concrete events or contain the meaning of solving or decomposing a double meaning, vague norms, conflicts between legal norms and the uncertainty of a legislation, while the position of jurisprudence in the legal system in Indonesia then the Judge is free to follow or not to the decisions of previous jugdes.

The Panel of Judges who decides the case by Decision No. 47/Pdt.G/2012/PN LSK has granted the request for the decisoir eed at the Lhokukon District Court Mosque as follows:

1. The existence of Exhibit P-I/T-II (Letter of Agreement dated 17 February 2012) which is a proof that shows there has been a sale and purchase transaction between the Plaintiff with the Defendants as much as 149.773 Kg with the price of Rp. 711.421.750,00.

2. Exhibit P-II.B, P-II.C, P-II.D, and P-II.E show that the invoice has never been paid by the Defendants to the Plaintiff.

In contrast to the opinion of the panel of judges who decide the case by Decision No. 16/Pdt.G/2012/PN STB The decisoir eed shall be made on the reasons that the Plaintiff can not find a document of authenticity in the form of Warkah so that the urgency of the application of the proof of the decisoir eed in order to convince the Judge.

Several factors affecting the confidence of the right to grant the decisoir eed are as follows. The stages of proof of civil cases in the courts generally judge based their thoughts related to 3 (three) principal events, namely acceptance of 
evidence, sorting of evidence and evidence of evidence. Acceptance acceptance process should rely on the rules contained in formal civil law, acceptance of evidence also through the use and adherence to the principles of evidencing to bring about a sense of justice and a due process in order to demonstrate compliance and adherence to the method of thinking correctly.

The sorting of evidence in a proofing event is only to match evidence with more events, whereas incompatible or contradictory evidence does not need to be accepted by the judge in his judgment. The process of matching evidence or sorting of evidence can be done at the time of proof or after proof when preparing legal considerations in the form of legal facts.

The evaluation of evidence in the trial is related to the description of basic concepts such as the provision of evidentiary value, the relationship between evidence (relevance), probability, generalization, reasoning, argumentation, and conclusion. The value of proof is based on the most important evidence or the number one proof, the inherent strength of evidence is the strength of external evidence, the force of formative proof, and the material evidentiary power in order to have the value of the perfect (volledig) and binding strength (bindende).

\section{Conclusion}

In the application of law, the element of Judge's conviction is very significant in determining a fact in civil cases conducted by actively taking the role of Judge. The role of the Judge's confidence in examining a civil case is related to an investigation conducted by the Judge to be absolutely convinced of the truth of the disputed fact. The Judge's active role is well done because of the authority granted by the provisions of the law of civil proceedings positive and Judge discretion. The activeness of the Judge in relation to the Judge's conviction in Case No. 02/Pdt.G/2012/PN-LSK can be seen from several things, namely: Judge's activeness in assessing evidence, Judge Activity in examining cases containing criminal elements, and Judge Activity in deciding based on the principle ex aquo et bono.

While in the case no. 16/Pdt.G/2012/PN STB there is a difference of perception between the panel of judges with the Parties in applying the decisoir eed is influenced by several factors such as the Judge's understanding of the decisoir eed, the understanding then gave birth to different interpretation of Article 156 HIR / 183 RBG governing decisoir eed and cultural factors (culture) of litigants who have been accustomed to problem-solving through oaths. The 
judge should have the same legal interpretation as the Parties because the Party who is under the decisoir eed also does not object to the request of the Plaintiff, otherwise, the community culture may be accommodated by the Judge.

Therefore, in conclusion, the application of the proof decisoir eed in a civil event is not relevant because it is far from a sense of legal certainty. The legal paradigm that develops in the handling of civil cases in addition to seeking formal truth begins to lead to the realization of material truth is limited because the Judge in civil cases may have to search the truth of facts that are adhered by the parties for the realization of justice based on the principle of freedom of Judges guaranteed by the constitution and the authority attached to the Judge. Therefore, one of the legal reforms that can be done is the provision in civil procedure law which affirms the inherent power of the Judge in leading the trial to bring about justice or avoid injustice.

In addition, the concept of arrangement towards the reform of the law of a national civil event relating to the proof decisoir eed should be another dissertation plus the Judge's conviction in line with the theory of material truth. The concept of evidentiary system prevailing in the country of Indonesia still has no uniformity in the view by legal experts and legal practitioners, therefore it is necessary to renew the civil procedure law with a new concept for the realization of legal certainty. The judge has great authority in relation to the control of evidence but is limited by the hierarchy of evidence. The future Arbitration of Criminal Proceedings should eliminate the need for a hierarchy of evidence (the order of evidence) and the evidentiary standard in civil procedure law in the form of all forms of evidence to be used as evidence as evidence which may be filed in court as long as the Judge accepts it as evidence and is free assess the evidence.

\section{References}

Fakhriah, Efa Laela. Perbandingan HIR dan RBg Sebagai Hukum Acara Perdata Positif Di Indonesia, Bandung: PT. Keni Media, 2015.

Fakhriah, Efa Laela. Bukti Elektronik dalam Sistem Pembuktian Perdata, Bandung: Alumni, 2011.

Mertokusumo, Sudikno. Hukum Acara Perdata Indonesia Edisi Revisi, Yogyakarta: PT. Liberty, 2013.

Muhammad, Abdulkadir. Hukum Perdata Indonesia, Bandung: PT. Citra Aditya Bakti, Bandung, 2012. 
Subekti, R. Hukum Pembuktian, Jakarta: PT. Pradnya Paramita, 2010.

Usman, Rachmadi. Perkembangan Hukum Perdata Dalam Dimensi Sejarah dan Politik Hukum di Indonesia, Jakarta: PT. Sinar Multi Press, 2003.

Yahya, M. Harahap. Hukum Acara Perdata:Gugatan, Persidangan, Penyitaan, Pembuktian, dan Putusan Pengadilan, Jakarta: Sinar Grafika, 2012. 


\section{JURNAL}

\section{CITA HUXUM INDONESIAN LAW JOURNAL}

\section{TECHNICAL GUIDANCE FOR AUTHORS OF CITA HUKUM JOURNAL}

1. Article must be original, not plagiarism, unpublished, and not under review for possible publication in other journals.

2. Article should be concept, research-based, and toughts;

3. Article should be written in Bahasa Indonesia or English

4. Article must contain of Law Science

5. Writing Guidance as follows:

a. Title is written by Capital maximum 12 words in the center

b. Name of authors are written completely, no degree, institutional affiliation, address, and email.

c. Abstract is written in Bahasa Indonesia or English maximum 120 words.

d. Systematycs of article:

1) Title

2) Name of authors (no title), name of affiliation, email

3) Abstract

4) Keywords, between 2-5 words

5) Introduction

6) Sub title (if need it)

7) Closing

8) Bibliography (The bibliography list contains all references in text originating from sources that are relevant and at least up to date (last 10 years).

e. Paper Sizes are $17,5 \times 24 \mathrm{~cm}$, up $2,5 \mathrm{~cm}$, down, $2,5 \mathrm{~cm}$, right $2,5 \mathrm{~cm}$, and left $2,5 \mathrm{~cm}$

f. Length of article is between $18-20$ pages with 1.0 line spacing , Palatyno Fond Style with 10 size.

g. Rule of citation. Direct citation if word is more than 4 lines separated from the text with 1.0 spacing with 9 font. However if citation less than 4 lines, it should be integrated in the text with double apostrof both in the first and in the end. Every citation is given number. Citation system is footnote not body note or endnote and use turabia system. Every article, book, and other source should be citated on the reference.

h. Citation for Quran and Hadist. For verse citation contains name of surah, number of surah and number of verse example: (Qs. Al Mumin [40]: 43). For Hadis citation, mention name of Perawi/Author, example (H. R al-Bukhari and Muslim) and printed hadist version. Hadist must be from standar hadist books (Kutub at-Tisah).

i. Footnote is written by Palatino Linotype style, size 8 , for any sources as follows:

1) Book: Author's name (without title), title of book (place publised: publisher, year of published), Version, Volume, Batch, Page. Example: Soerjono Soekanto, Pokok-Pokok Sosiologi Hukum, (Jakarta: Rajawali Press, 1986), p. 10. 
2) Translated Book. Example: Roscoe Pound, Pengantar Filsafat Hukum: Book III, translated by Moh. Radjab, (Jakarta: Bharata, 1963), p.15.

3) Journal, example: Nur Rohim Yunus, "Kontroversi Pembentukan Perppu No. 1 Tahun 2013 tentang Mahkamah Konstitusi Dalam Ranah Kegentingan Yang Memaksa", Jurnal Cita Hukum, Volume 1 Number 1 (2014), p.157.

4) Article as a part of book (antology). Contoh: Hikmahanto Juwana, "Penegakan Hukum dalam Kajian Law and Development: Problem dan Fundamen bagi Solusi Indonesia", in Muhammad Tahir Azhary, Beberapa Aspek Hukum Tata Negara, Hukum Pidana, dan Hukum Islam, (Jakarta: Kencana Prenada Media Group, 2012), p.127.

5) Article from internet, example: Ahmad Tholabie Kharlie, "Problem Yuridis RUU Syariah" in http://ahmadtholabi.com/2008/03/03problem-yuridis-ruu-syariah, downloaded on March 20, 2012.

6) Article from magazine, example: Susilaningtias, "Potret Hukum Adat pada Masa Kolonial", in Forum Keadilan, No. 17, August 20, 2017.

7) Article in Seminar, example: Jimly Asshidiqqie, "Kedudukan Mahkamah Konstitusi dalam Struktur Ketatanegaraan Indonesia", paper presented on public lecture at faculty of law Universty Sebelas Maret, Surakarta on March 2, 2014.

j. Bibliography. Bibliography is written alphabeticaly, last author's name is in the first of name, example:

1) Book: Soekanto, Soerjono, Pokok-Pokok Sosiologi Hukum, Jakarta: Rajawali Press, 1986.

2) Translated Book. Example: Pound, Roscoe, Pengantar Filsafat Hukum: Book III, translated by Moh. Radjab, Jakarta: Bharata, 1963.

3) Journal, example: Rohim, Nur, "Kontroversi Pembentukan Perppu No. 1 Tahun 2013 tentang mahkamah konstitusi dalam ranah kegentingan yang memaksa", Jurnal Cita Hukum, Volume 1 Number 1 (2014).

4) Article as a part of book (antology). example: Juwana, Hikmahanto, "Penegakan Hukum dalam Kajian Law and Development: Problem dan Fundamen bagi Solusi Indonesia", in Muhammad Tahir Azhary, Beberapa Aspek Hukum Tata Negara, Hukum Pidana, dan Hukum Islam, Jakarta: Kencana Prenada Media Group, 2012.

5) Article from internet, example: Kharlie, Ahmad Tholabie, "Problem Yuridis RUU Syariah" in http://ahmadtholabi.com/2008/03/03problem-yuridis-ruu-syariah, downloaded on March 20, 2012.

6) Article from magazine, example: Susilaningtias, "Potret Hukum Adat pada Masa Kolonial", in Forum Keadilan, No. 17, August 20, 2016.

7) Article in Seminar, example: Asshidiqqie, Jimly, "Kedudukan Mahkamah Konstitusi dalam Struktur Ketatanegaraan Indonesia", paper presented on public lecture at faculty of law Universty Sebelas Maret, Surakarta on March 2, 2014.

k. Closing, article is closed by conclusion;

I. Short biography: author's biography contains full name, title, institution, education and other academic experts.

6. Every article that doesnt fufill all requirements to this guidance will give it back to the author for revision.

7. Article must be submitted to editors at least 3 months before publishing (June and December) with uploading via OJS to http://journal.uinjkt.ac.id/index.php/citahukum or e-mail to jurnal.citahukum@uinjkt.ac.id.] 


\section{PEDOMAN TEKNIS PENULISAN BERKALA ILMIAH JURNAL CITA HUKUM}

1. Artikel adalah benar-benar karya asli penulis, tidak mengandung unsur plagiasi, dan belum pernah dipublikasikan dan/atau sedang dalam proses publikasi pada media lain yang dinyatakan dengan surat pernyataan yang ditandatangani di atas meterai Rp 6000;

2. Naskah dapat berupa konseptual, resume hasil penelitian, atau pemikiran tokoh;

3. Naskah dapat berbahasa Indonesia atau Inggris;

4. Naskah harus memuat informasi keilmuan dalam ranah ilmu hukum Positif;

5. Aturan penulisan adalah sebagai berikut:

a. Judul. Ditulis dengan huruf kapital, maksimum 12 kata diposisikan di tengah (centered);

b. Nama penulis. Ditulis utuh, tanpa gelar, disertai afiliasi kelembagaan dengan alamat lengkap, dan alamat e-mail;

c. Abstrak. Ditulis dalam bahasa Indonesia dan bahasa Inggris masing-masing hanya 120 kata saja;

d. Sistematika penulisan naskah adalah sebagai berikut:

1) Judul;

2) Nama penulis (tanpa gelar akademik), nama dan alamat afiliasi penulis, dan e-mail;

3) Abstrak;

4) Kata-kata kunci, antara 2-5 konsep yang mencerminkan substansi artikel;

5) Pendahuluan;

6) Sub judul (sesuai dengan keperluan pembahasan);

7) Penutup; dan

8) Pustaka Acuan (hanya memuat sumber-sumber yang dirujuk dan sedapat mungkin terbitan 10 tahun terakhir).

e. Ukuran kertas yang digunakan ukuran $17,5 \times 24 \mathrm{~cm}$, margin: atas $2,5 \mathrm{~cm}$, bawah $2.5 \mathrm{~cm}$, kiri 2,5 $\mathrm{cm}$, dan kanan 2,5 cm;

f. Panjang Naskah antara 18 s.d. 20 halaman, spasi 1, huruf Palatino Linotype, ukuran 10;

g. Pengutipan kalimat. Kutipan kalimat ditulis secara langsung apabila lebih dari empat baris dipisahkan dari teks dengan jarak satu spasi dengan ukuran huruf 9 point. Sedangkan kutipan kurang dari empat baris diintegrasikan dalam teks, dengan tanda apostrof ganda di awal dan di akhir kutipan. Setiap kutipan diberi nomor. Sistem pengutipan adalah footnote (bukan bodynote atau endnote). Penulisan footnote menggunakan sistem turabian. Setiap artikel, buku, dan sumber lainnya yang dikutip harus tercantum dalam pustaka acuan;

$h$. Pengutipan Ayat Alquran dan Hadis. Ayat yang dikutip menyertakan keterangan ayat dalam kurung, dengan menyebut nama surah, nomor surah, dan nomor ayat, seperti (Q.S. al-Mu'min [40]: 43). Pengutipan Hadis menyebutkan nama perawi (H.r. al-Bukhārī dan Muslim) ditambah referensi versi cetak kitab Hadis yang dikutip. Hadis harus dikutip dari kitab-kitab Hadis standar (Kutub al-Tis'ah);

i. Cara pembuatan footnote. Footnote ditulis dengan font Palatino Linotype, Size 8, untuk pelbagai sumber, antara lain:

1) Buku: nama utuh penulis (tanpa gelar), judul buku (tempat terbit: penerbit, tahun terbit), cetakan, volume, juz, halaman. Contoh: Soerjono Soekanto, Pokok-pokok Sosiologi Hukum, (Jakarta: Rajawali Pers, 1986), h. 10.

2) Buku terjemahan, contoh: Roscoe Pound, Pengantar Filsafat Hukum: Buku III, diterjemahakan oleh Moh. Radjab, (Jakarta: Bharata, 1963), h. 15;

1) Jurnal, contoh: Nur Rohim Yunus, "Kontroversi Pembentukan Perppu No. 1 Tahun 2013 tentang mahkamah konstitusi dalam ranah kegentingan yang memaksa", dalam Jurnal Cita Hukum, Vol. I, No. 1, Juni 2014, h. 157. 
2) Artikel sebagai bagian dari buku (antologi), contoh: Hikmahanto Juwana, "Penegakan Hukum dalam Kajian Law and Development: Problem dan Fundamen bagi Solusi Indonesia", dalam Muhammad Tahir Azhary, Beberapa Aspek Hukum Tata Negara, Hukum Pidana, dan Hukum Islam, (Jakarta: Kencana Prenada Media Gorup, 2012), h.127.

3) Artikel dari internet, contoh: Ahmad Tholabi Kharlie, "Problem Yuridis RUU Syariah" dalam http://ahmadtholabi.com/2008/03/03/problem-yuridis-ruu-syariah, diunduh pada 20 Maret 2012.

4) Artikel dari majalah, contoh: Susilaningtias, "Potret Hukum Adat pada Masa Kolonial", dalam Forum Keadilan, No. 17, 20 Agustus 2006.

5) Makalah dalam seminar, contoh: Jimly Asshiddiqie, "Kedudukan Mahkamah Konstitusi dalam Struktur Ketatanegaraan Indonesia", Makalah disampaikan dalam Kuliah Umum Fakultas Hukum Universitas Sebelas Maret, Surakarta, pada 2 Maret 2004.

j. Pustaka Acuan: daftar pustaka acuan ditulis sesuai urutan abjad, nama akhir penulis diletakkan di depan. Contoh:

1) Buku, contoh: Soekanto, Soerjono, Pokok-pokok Sosiologi Hukum, Jakarta: Rajawali Pers, 1986.

2) Buku terjemahan, contoh: Pound, Roscoe, Pengantar Filsafat Hukum: Buku III, diterjemahakan oleh Moh. Radjab, Jakarta: Bharata, 1963.

3) Jurnal, contoh: Rohim, Nur, "Kontroversi Pembentukan Perppu No. 1 Tahun 2013 tentang mahkamah konstitusi dalam ranah kegentingan yang memaksa", dalam Jurnal Cita Hukum, Vol. I, No. 1, Juni 2014.

4) Artikel sebagai bagian dari buku, contoh: Juwana, Hikmahanto, "Penegakan Hukum dalam Kajian Law and Development: Problem dan Fundamen bagi Solusi Indonesia", dalam Muhammad Tahir Azhary, Beberapa Aspek Hukum Tata Negara, Hukum Pidana, dan Hukum Islam, Jakarta: Kencana Prenada Media Gorup, 2012.

5) Artikel yang dikutip dari internet, contoh: Kharlie, Ahmad Tholabi, "Problem Yuridis RUU Syariah" dalam http://ahmadtholabi.com/2008/03/03/problem-yuridis-ruu-syariah, diunduh pada 20 Maret 2012.

6) Majalah, contoh: Susilaningtias, "Potret Hukum Adat pada Masa Kolonial", dalam Forum Keadilan, No. 17, 20 Agustus 2006.

7) Makalah dalam seminar, contoh: Asshiddiqie, Jimly, "Kedudukan Mahkamah Konstitusi dalam Struktur Ketatanegaraan Indonesia", Makalah disampaikan dalam Kuliah Umum Fakultas Hukum Universitas Sebelas Maret, Surakarta, pada 2 Maret 2004.

k. Penutup: artikel ditutup dengan kesimpulan;

I. Biografi singkat: biografi penulis mengandung unsur nama (lengkap dengan gelar akademik), tempat tugas, riwayat pendidikan formal (S1, S2, S3), dan bidang keahlian akademik;

6. Setiap naskah yang tidak mengindahkan pedoman penulisan ini akan dikembalikan kepada penulisnya untuk diperbaiki.

7. Naskah sudah diserahkan kepada penyunting, selambat-lambatnya tiga bulan sebelum waktu penerbitan (Juni dan Desember) dengan mengupload langsung via OJS ke alamat: http://journal.uinjkt.ac.id/index.php/citahukum atau via e-mail ke: jurnal.citahukum@uinjkt.ac.id.[] 
in Collaboration with :

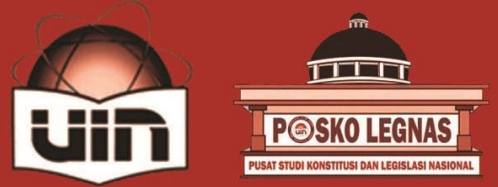

Indexed by :
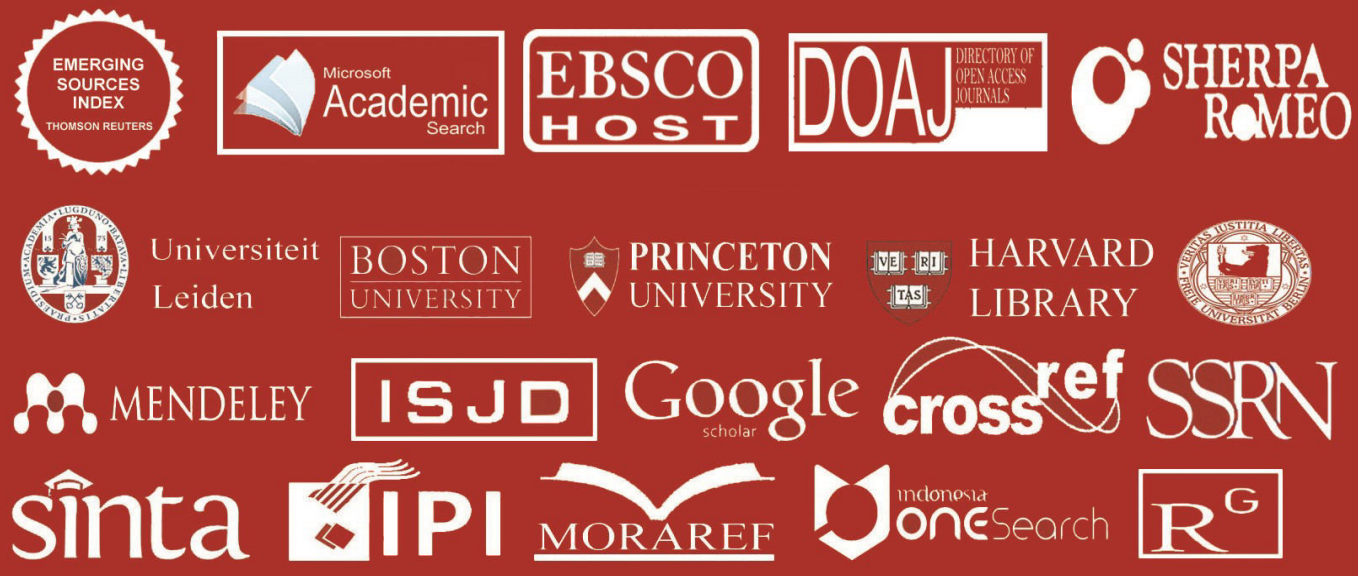

JURNAL CITA HUKUM is a peer-reviewed journal on Indonesian Law Studies published biannual (June \& December) by Faculty of Sharia and Law Universitas Islam Negeri Syarif Hidayatullah Jakarta in cooperation with Center for the Study of Constitution and National Legislation (POSKO-LEGNAS). JURNAL CITA HUKUM aims primarily to facilitate scholarly and professional discussions over current developments on legal issues in Indonesia as well as to publish innovative legal researches concerning Indonesian laws.
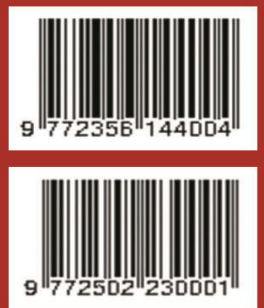